\title{
Tolerance toward migrants among Italian adolescents and young adults: The role of civic and political participation
}

\author{
Iana Tzankova*, Antonella Guarino*, Davide Mazzoni**
}

\begin{abstract}
This paper aims at clarifying the relationship between being involved in different forms of participation and tolerance toward migrants in young people. Almost 3000 participants from two European-funded research projects - FP7 PIDOP and H2020 CATCH-EyoU - answered a questionnaire that measured socio-demographics variables, the dimension of fairness in school climate, different forms of civic and political participation, and tolerance toward migrants and refugees. The results are consistent between the two studies, showing that civic participation demonstrated a major positive effect on tolerance. Being older, female, born in a foreign country, having more educated parents, and perceiving fairness at school, were also conditions, which sustained the development of tolerance.
\end{abstract}

Key words: tolerance, migrants, adolescents, young adults, civic participation, political participation

Riassunto. La tolleranza di adolescenti e giovani adulti italiani verso i migranti: il ruolo della partecipazione civica e politica

Questo studio ha lo scopo di chiarire la relazione tra il coinvolgimento in diverse forme di partecipazione e la tolleranza verso i migranti tra i giovani. Circa 3000 adolescenti e giovani contattati nell'ambito di due progetti di ricerca Europei - FP7 PIDOP e H2020 CATCH-EyoU - hanno risposto a questionari che misuravano variabili socio-demografiche, la dimensione di giustizia nella percezione del clima scolastico, diverse forme di partecipazione civica e politica, e la tolleranza verso migranti e rifugiati. I risultati sono coerenti tra i due studi, dimostrando un

* Dipartimento di Psicologia, Università di Bologna, iana.tzankova2@unibo.it; antonella. guarino2@unibo.it

** Dipartimento di Psicologia, Università di Milano-Bicocca, davide.mazzoni@unimib.it

Psicologia di Comunità (ISSN 1827-5249, ISSNe 1971-842X), 1, 2019

DOI: 10.3280/PSC2019-001005 
effetto positivo della partecipazione civica sulla tolleranza. Ulteriori fattori che risultano incrementare la tolleranza sono: avere un'età maggiore, essere donne e nate/ $\mathrm{i}$ in un paese estero, avere genitori con livello d'istruzione più alto, e percepire un clima di giustizia a scuola.

Parole chiave: tolleranza, migranti, adolescenti, giovani adulti, partecipazione civica, partecipazione politica

\section{Introduction}

In the last two decades, following the growing political and scholarly debates about international immigration, social scientists' interest for tolerance or intolerance toward migrants has flourished (Hermann, Van Zalk \& Kerr, 2014; Rapp, 2017). The lack of tolerance implies the rejection of people whom we perceive as different, for example, members of a social or ethnic group other than ours. When it is oriented towards foreigners it represents a real problem and in many countries, it is often related to phenomena like xenophobia, antisemitism, romaphobia and antigypsyism (e.g., Ramberg, 2005). The manifestations of intolerance comprise a number of actions, which range from avoidance and hate speech, to physical injury and even murder. Tolerance has thus important consequences for democratic life, because people's efforts to control their negative prejudices and tolerate other groups are crucial to sustain democratic norms (Freitag \& Rapp, 2015). For all these reasons, the study of tolerance and of the factors that can promote or obstacle its development, increasingly becomes an important issue for researchers (Côté \& Erickson, 2009; Gniewosz \& Noack, 2008).

Tolerance requires a reciprocal respect of our rights as human beings even if it does not entail solving all differences (see Rapp, 2017). It rather implies the ability to put up with something potentially disagreeable (Freitag \& Rapp, 2015; Langerack, 1994; Rapp, 2017), accepting the fact that human beings, naturally diverse in their appearance, situation, speech, behavior and values, have the right to live in peace and to be as they are (UNESCO, 1995, see also UNESCO, 1997). With specific reference to immigration, tolerance implies the belief, based on equalitarian principles and a political conviction, that migrants and non-migrants should be treated equally (Van Zalk \& Kerr, 2014). This requires overcoming personal prejudices, just and impartial legislation, law enforcement and judicial and administrative process to support their rights (UNESCO, 1995).

Very important insights about tolerance come from the extensive research that, through different approaches, has focused on related phenomena, such as national and racial prejudice (Raabe \& Beelmann, 2011). However, there has been a consistent lack of systematic and specific interest in 
intergroup tolerance and prosocial behaviors as emerged from recent literature reviews of social psychology research (Verkuyten \& Yogeeswaran, 2017; Verkuyten, 2018). Moreover, the processes through which individuals develop tolerance (or intolerance) toward migrants remain partially unclear (see also: Mazzoni et al., 2019). In this manuscript we suggest that the study of tolerance in adolescence and young adulthood in relation to practices of civic and political participation appears of particular interest.

\subsection{Tolerance attitudes during adolescence and young adulthood}

Studying tolerance and intergroup attitudes, specifically towards migrants, is especially relevant in young people. Particularly during adolescence, individuals become part of new networks and gradually get in contact with a variety of others who are very different from themselves and from their families. Peer relationships in adolescence, seem to have crucial importance in the socialization of intergroup attitudes and behaviors (e.g., Brechwald \& Prinstein, 2011; Van Zalk et al., 2013), and contact with migrants at this age can have a beneficial influence (Wölfer et al., 2016). Furthermore, adolescents tend to enlarge their social horizon and increasingly define themselves as members of multiple groups (e.g., Benish Weisman et $a l ., 2015)$. Indeed, in this period the development of social identity undergoes crucial changes related to the expansion of social cognition. For example, during this phase of life there is a growing understanding of group norms (Abrams \& Rutland, 2008), but also the development of moral beliefs (Rutland, Killen \& Abrams, 2010), as well as political and ethnic identities (Emler, 2005; French et al., 2006). During adolescence individuals consolidate also their abstract reasoning abilities, which represent a prerequisite for understanding tolerance principles (Hjerm, 2009; Rydgren, 2004). All of these cognitive and social developmental transformations make adolescence an especially sensitive period for acquiring tolerant attitudes toward migrants.

During the subsequent developmental stage, often referred to as "emerging adulthood", individuals also go through many different transitions (regarding family, occupation, housing, etc.), which are characterized by identity exploration, instability, and concern for the self, accompanied by the adoption of new social roles (Arnett, 2004). For example, from the age of 18 in many countries, it is possible to vote in political elections. This determines also new responsibilities toward society and more opportunities for the development of a political identity through experience than in adolescence (Emler, 2005). Moreover, it has been argued that young adulthood 
acquires particular importance for the development of intercultural maturity, which is conducive to increasing tolerance and openness towards diversity (King \& Magolda, 2005; Kubal et al., 2003). It has been shown, for example, that developmental gains in identity development, moral reasoning and empathy in emerging adulthood make it a crucial moment to address tolerance and respect for human differences (Gerson \& Neilson, 2014). For these reasons, the levels of tolerance that individuals demonstrate in this life period may have important practical and societal consequences.

Recent research has focused on a wide range of influencing factors that can be placed, according to an ecological approach, across individual and social-environmental levels of explanation (i.e., Ashy, 2011). Moreover, it is also reasonable to assume that the effect of some factors is not the same across development stages. In the next paragraphs, we provide some insights about the process of tolerance promotion suggesting some specific factors, which may be particularly relevant during adolescence and young adulthood.

\subsection{Participation and tolerance toward migrants}

Civic engagement among youth has been linked with numerous personal and community benefits (e.g., Flanagan \& Levine, 2010). There are some reasons to hypothesize that it also may have an impact on tolerance development and that young individuals who take part in different forms of civic and political participation can become more tolerant than their peers. This idea is consistent with the work of other scholars, who have argued that both social networks and voluntary associations are forms of social capital and participating in them can contribute to positive outcomes like tolerance of diversity (Putnam, 2000). It is argued, in this sense, that civic engagement is a form of bridging capital that ties individuals with people unlike themselves and this exposure is beneficial for becoming more tolerant of diversity (Wise \& Driskell, 2017). Indeed, taking part in association activities brings people into frequent contact with others who are very different from themselves, while sharing common interests, and the literature suggests that people with more diversified networks can become more tolerant (Coté \& Erickson, 2009; Rapp \& Freitag, 2014). Engagement on civic and political issues generally puts individuals in a collective collaborative setting, where there is group interaction and cooperative efforts. Such situation should promote the development of trust in others and norms of reciprocity, and more generally acceptance and understanding of societal diversity (Rapp \& Freitag, 2014). Some preliminary empirical confirmation de- 
rives, for example, from the results of the study by Escandell (2004), who showed that in Southern Europe there was a strong significant association between trust in institutions (such as NGOs and voluntary organizations) and decreased levels of anti-immigrant sentiment and intergroup conflict.

However, it is still not clear which kind of participation could be associated with different levels of tolerance, and it is reasonable to believe that different kinds of participatory activities can also have a positive, negative, or null impact. Civic engagement, like volunteering, for example, could provide more opportunities to understand and engage with issues in communities different from one's own. Political and online participation, however, may not be necessarily related to connecting with diverse issues and people and, thus, their relation to tolerance promotion is still not clear. Moreover, it has been noted that political involvement is generally lower in adolescence (Schulz et al., 2010), when there are less opportunities for this type of engagement in comparison to volunteering and community activities, so it could be a less relevant factor for the promotion of tolerance.

\subsection{Other factors promoting tolerance toward migrants}

The literature showed that some background socio-demographic factors might be related to the development of tolerance. In particular, females showed more tolerant attitudes than males (e.g., Torney-Purta et al., 2001). Of course, being migrant represents a specific condition which may lead to perceiving migrants as part of the same in-group (Tajfel \& Turner 1979), and thus to a more tolerant attitude toward them. Finally, it emerges in the study that students attending the high college-bound track reported less antiforeigner attitudes, as did students whose parents had a more sophisticated educational background (Gniewosz \& Noack, 2008). The authors concluded that more educated parents hold more tolerant views themselves (cf. Emler and Frazer, 1999) and this influences their offspring in turn by processes of transmission.

Moreover, other factors that have to do with the school context can play an important role in favouring tolerance in adolescence. In a study with a large sample of German adolescent students, Gniewosz \& Noack (2008) found that fairness in the classroom was negatively related to intolerance: students who perceived their teachers as treating them in a fair manner reported more tolerant views of foreigners. This result was consistent with the previous result that a teacher-student relationship described as positive and democratic is positively associated with adolescents' democratic worldview (Hahn, 1999). 


\subsection{Aims}

The present work was aimed at verifying the relationship between engagement in different forms of participation during adolescence and young adulthood, and tolerance toward migrants. For this purpose, we set up two studies based on two different sets of Italian data, collected as part of the European-funded research projects FP7 PIDOP (Processes Influencing Democratic Ownership and Participation) and H2020 CATCH-EyoU (Constructing Active Citizenship with European Youth).

We hypothesized that being involved in different participatory contexts would represent an opportunity for developing tolerant attitudes (H1).

We also controlled for the impact of school climate (fairness) and of different sociodemographic variables. Indeed, in accordance with Gniewosz \& Noack (2008), we expected that perceived fairness at school was associated with higher levels of tolerance $(\mathrm{H} 2)$. Moreover, according to the literature, we expected that females had more positive attitudes than males, and that similar results are found also for tolerance (e.g., Torney-Purta et al., 2001) (H3). Migrant participants, as belonging to the same in-group, should have more positive attitudes, and thus more tolerance (e.g., Tajfel \& Turner, 1979) (H4). Finally, in line with a previous study (Gniewosz \& Noack, 2008), we expected that students with higher-educated parents would report more tolerant views towards foreigners (H5).

\section{Study 1}

\subsection{Method}

In Study 1 we investigated the relationship between different forms of civic and political participation, and tolerance toward migrants. The sample consisted of 1240 Italian adolescents and young adults ${ }^{1}$. Participants completed a paper questionnaire and the following variables were considered for the analyses: age, gender, migrant status, parents' education, different forms of participation, and tolerance toward migrants. The study was approved by the Bioethic Board of the University of Bologna.

Females were $46.5 \%$ and the mean age was 20.07 years (min. 14, max. 29). More specifically, the age of adolescents $(n=600 ; 48.4 \%)$, ranged from 14 to 19 years old. The age of young adults $(640 ; 51.6 \%)$ ranged from

\footnotetext{
${ }^{1}$ The research reported in Study 1 was supported by a grant received by the European Commission's 7th Framework Programme FP7-SSH-2007-1, Grant Agreement N. 225282 Processes Influencing Democratic Ownership and Participation (PIDOP) (2009-2012).
} 
20 to 29 years old. Migrant status was assessed asking if participants were born in the same country, in which data were collected (74.2\%) or in another country $(25.8 \%)$. The levels of mother's and father's education was assessed considering if they reached a bachelor/master degree (16.7\% of both mothers and fathers) or a lower lowed degree (83.3\%).

For the purposes of this study, participation was assessed asking if, in the last year, they took part in a list of activities, assessing civic (donate money, do volunteer work, take part in concerts or events with a social or political cause), online (e.g. linking news or videos with a social or political content, discuss social or political questions on the net, connect to a group dealing with social or political issues on a social network) and political unconventional (write political messages or graffiti on walls, political actions which might be considered illegal) participation. Possible answers ranged from 1 ("never") to 5 ("very often"). Results of the rotated factor analysis are reported in Table 1. Each item showed a loading factor higher than .40 on a single factor (and lower than .30 in the others).

Tab. 1 - Study 1 items assessing participation: Rotated factor matrix

\begin{tabular}{lccc} 
& \multicolumn{3}{c}{ Factor } \\
\cline { 2 - 4 } & $\begin{array}{c}1 \\
\text { Online }\end{array}$ & $\begin{array}{c}\text { Political } \\
\text { (unconventional) }\end{array}$ & Civic \\
\hline Link news or music or videos with a social \\
$\begin{array}{l}\text { or political content to my contacts } \\
\begin{array}{l}\text { Discuss societal or political questions on } \\
\text { the net }\end{array}\end{array}$ & .807 & \\
$\begin{array}{l}\text { Connect to a group on Facebook (or similar } \\
\text { online social networks) dealing with social } \\
\text { or political issues }\end{array}$ & .752 & \\
$\begin{array}{l}\text { Participate in political actions that might be } \\
\text { considered illegal (e.g., burning a flag, } \\
\text { throwing stones, etc.) }\end{array}$ & & \\
$\begin{array}{l}\text { Write political messages or graffiti on walls } \\
\text { Distribute leaflets with a political content }\end{array}$ & & \\
$\begin{array}{l}\text { Donate money to a social or political } \\
\text { cause/organization }\end{array}$ & & .775 \\
$\begin{array}{l}\text { Do volunteer work } \\
\text { Take part in concerts or a fundraising event } \\
\text { with a social or political cause }\end{array}$ & & .418 \\
\hline Note: Factor loadings $<.30$ are not shown. & & .515 \\
\end{tabular}

The alpha of the items assessing online participation was acceptable $(\alpha$ $=.86)$ and a mean index was used in the analysis $(M=2.11 ; S D=1.14)$. A similar procedure was followed also for items assessing political unconven- 
tional $(\alpha=.71 ; M=1.25 ; S D=.60)$, and civic participation $(\alpha=.53 ; M=$ $1.83 ; S D=.81)$. The values of the Cronbach's $\alpha$ of civic participation appeared quite low. However, $\alpha$ measures not only the homogeneity of the items, but also the homogeneity of what is being assessed (Streiner, 2003): even seemingly unidimensional constructs, participation behaviors can be conceptualized having a number of different aspects. Moreover, the low alpha could be affected by the small length of the scale (Cortina, 1993; Streiner, 2003). For all these reasons and also for comparison purposes with Study 2, we decided to keep these three items subscale as a measure of civic participation.

Tolerance was assessed through four items measuring the support for some migrants' rights: to maintain their traditions and cultural heritage, to preserve their own languages, to earn the same wage when doing the same job as any other person, and to be granted with the same rights as any other person. Answers were provided on a 5-point scale, ranging from 1 ("strongly disagree") to 5 ("strongly agree"). A mean index was used in the analysis $(\alpha=.79 ; M=3.70 ; S D=.98)$.

The analyses were conducted separately among adolescents and young adults using the software SPSS 21. The values of skewness and kurtosis of tolerance, online and civic participation were lower than 1.3. Only the value of kurtosis of political unconventional participation was slightly higher than West, Finch and Curran (1996). After correlations, tolerance toward migrants was regressed through Univariate GLM procedure on the following variables: age, gender, migrant status, parents' education, and the three forms of participation.

\subsection{Results}

Table 2 presents the correlations between different forms of participation (online, unconventional, and civic) and tolerance toward migrants.

Table 3 presents the results of the regression analysis. Civic participation showed a significant effect on tolerance toward migrants in both subsamples (adolescents and young adults), while online participation showed a significant effect only among young adults. Other results, about fairness at school and socio-demographics will be commented in detail in the general discussion. 
Tab. 2 - Correlations between participation and tolerance among adolescents and young adults: Study 1

\begin{tabular}{lcccc}
\hline & 1. & 2. & 3. & 4. \\
\hline $\begin{array}{l}\text { 1. Tolerance toward migrants } \\
\text { 2. Online participation }\end{array}$ & .081 & $.174^{* *}$ & $.098^{*}$ & $.162^{* *}$ \\
$\begin{array}{l}\text { 3. Unconventional participa- } \\
\text { tion }\end{array}$ & $.109^{*}$ & $.452^{* *}$ & - & $.307^{* *}$ \\
\begin{tabular}{l} 
4. Civic participation \\
\hline
\end{tabular} & $.134^{* *}$ & $.395^{* *}$ & $.419^{* *}$ & $.311^{* *}$ \\
\hline
\end{tabular}

Notes: Pearson's correlations are reported.

${ }^{*} p<.01 ;{ }^{* *} p<.001$; Correlations for young adults are presented above the diagonal, and correlations for adolescents are presented below the diagonal.

Tab. 3 - Multilinear regression results: Study 1. Dependent variable: Tolerance toward migrants

\begin{tabular}{lcccc}
\hline & \multicolumn{2}{c}{ Adolescents } & \multicolumn{2}{c}{ Young adults } \\
\hline Variables & $\mathrm{F}$ & $p$ & $\mathrm{~F}$ & $p$ \\
& & & & \\
Migrant status & 140.34 & .000 & 18.13 & .000 \\
Gender (F) & 5.86 & .016 & 14.22 & .000 \\
Mothers' education & 1.13 & .288 & 0.81 & .368 \\
Father's education & 0.56 & .455 & 1.48 & .225 \\
Online participation & 1.42 & .234 & 7.34 & .007 \\
Unconventional partic- & 0.21 & .645 & 0.31 & .575 \\
ipation & & & & \\
Civic participation & 4.54 & .034 & 4.07 & .044 \\
& & & & \\
$\mathrm{R}^{2}$ & .231 & & .092 & \\
Adjusted $\mathrm{R}^{2}$ & .221 & & & \\
\hline
\end{tabular}

\section{Study 2}

\subsection{Method}

In Study 2 we investigated the relationship between different forms of participation, school climate and tolerance toward migrants and refugees. The recruitment strategy was targeted at young people between 14 and 30 years old. After receiving an invitation from the researchers and a presentation of the aims of the study, participants decided to take part in the study 
on a voluntary basis. The study was approved by the Bioethic Board of the University of Bologna.

The sample consisted of 1732 Italian adolescents and young adults ${ }^{2}$. As in Study 1, the following socio-demographic variables were considered for the analyses of the present study: age, gender, migrant status, and parents' education. Moreover, in accordance with our second hypothesis (H2) and Gniewosz and Noack (2008) we assessed also fairness at school. Furthermore, with respect to Study 1, considering the recent refugee crisis (Bansak, Hainmueller \& Hangartner, 2016), we decided to introduce also an assessment of tolerance toward refugees.

Females were $60.7 \%$ of the sample and mean age was 19.73 years (min. 15, max. 30). More specifically, the age of "adolescents" $(n=829 ; 47.8 \%)$, ranged from 15 to 19 years old. The age of "young adults" ( $n=903$; $52.2 \%$ ) ranged from 20 to 30 years old. Migrant status was assessed, as in Study 1, asking if participants were born in the same country in which data were collected (94.4\%) or in another country $(5.6 \%)$. As in Study 1, the levels of mother's and father's education was assessed considering if they reached a bachelor/master's degree (fathers: $21.9 \%$; mothers: $25.6 \%$ ) or a lower degree.

The measure of school climate was assessed only in the adolescents' group and focused on perceived fairness (e.g. "our teachers treat us fairly"; "the rules in our school are fair")". The correlation between the two items was quite high $(r=.54 ; p<.001)$ and a mean index was used in the analy$\operatorname{sis}(M=3.23 ; S D=.88)$.

Participation was assessed asking if, in the last year, they took part in a list of activities, which partially differed from study one, assessing four types of participation: online, civic, conventional political, and protest. Results of the rotated factor matrix, which are reported in Table 4, showed a four factors structure. Each item showed a loading factor higher than .40 in a single factor (and lower than .30 in the others). Online participation (civic and political) includes 3 items similar to Study 1. A mean index was thus used for the analyses $(\alpha=.84 ; M=2.22 ; S D=1.16)$. Civic participation was measured through 3 items, similarly to Study 1, with even higher values of Cronbach's $\alpha(\alpha=.70)$. A mean index was thus used for the analyses

\footnotetext{
${ }^{2}$ The research presented in Study 2 is based on data collected under CATCH-EyoU project funded by European Union, Horizon 2020 Programme, Constructing AcTive CitizensHip with European Youth: Policies, Practices, Challenges, and Solutions (2015-2018) (www.catcheyou.eu) [Grant Agreement No 649538]. The database used for this article is accessible at the following link: http://amsacta.unibo.it/id/eprint/6146.
} 
$(M=2.28 ; S D=.99)$. Conventional political participation (like working for a political party or for a political candidate) includes 3 items, and also in this case a mean index was calculated $(\alpha=.80 ; M=1.25 ; S D=.64)$. Protest was measured through 3 items assessing different protest behaviors (e.g., taking part in a political event where there was a physical confrontation with opponents; taking part in an occupation of a building or a public space) and a mean index was used in the analysis $(\alpha=.66 ; M=1.15 ; S D=$ $.41)$.

Tab. 4 - Study 2 items assessing participation: Rotated factor matrix

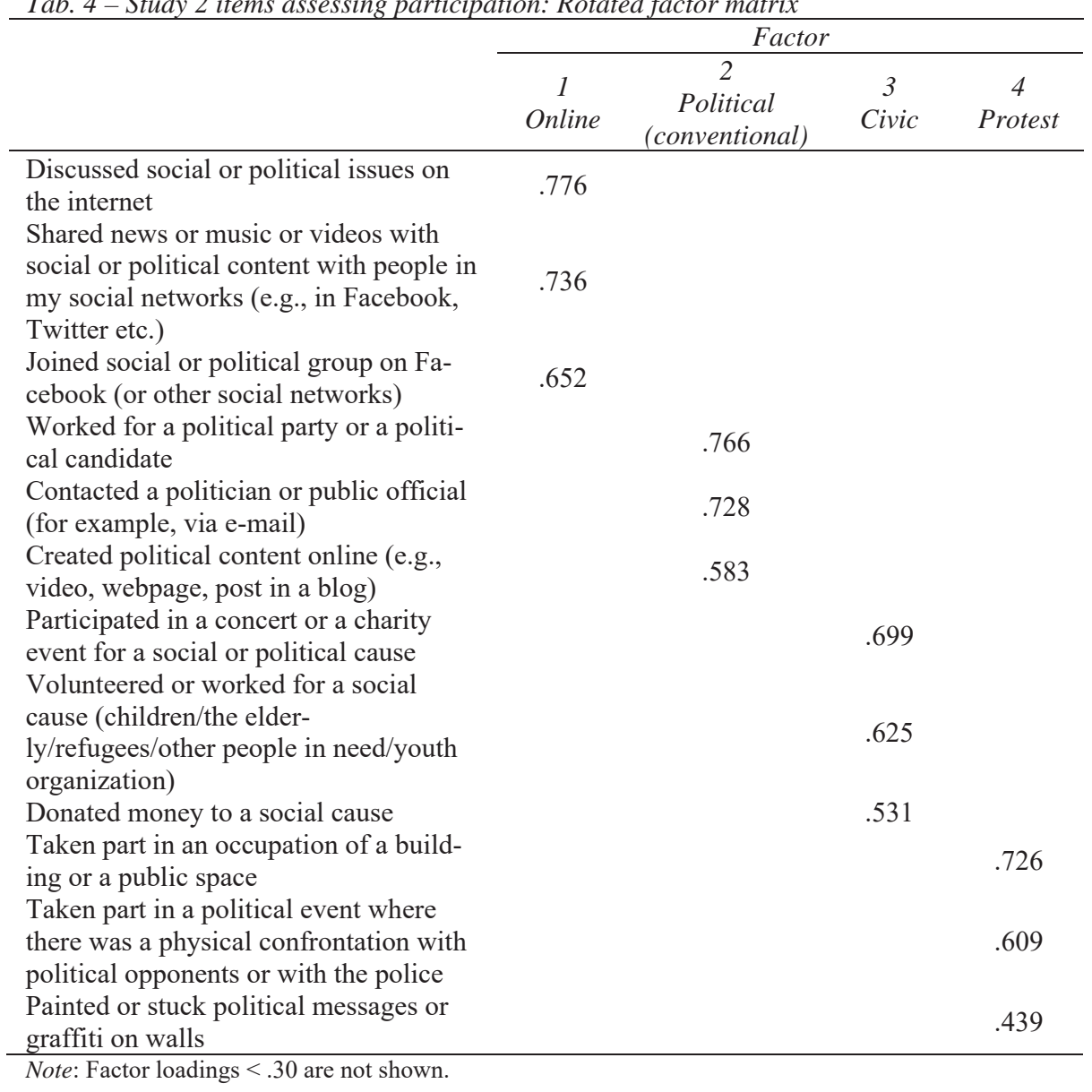

Tolerance toward migrants was assessed through three items ("migrants should have the right to maintain their traditions and cultural heritage", "migrants should have the right to preserve their own language", "migrants 
have a tendency to take job opportunities from local people" - reversed item). The possible answers ranged from 1 ("strongly disagree") to 5 ("strongly agree"). The alpha of the items assessing tolerance toward migrants was acceptable, and a mean index was thus used in the analysis $(\alpha=$ $.71 ; M=3.43 ; S D=1.98)$.

Tolerance toward refugees was assessed through three items ("I feel that refugees should have the right to maintain their traditions and cultural heritage", "I feel that our government does not do enough to help refugees", "I feel that our country has enough economic problems and that is why we cannot afford to help refugees" - reversed item). For these items, the possible answers ranged from 1 ("strongly disagree") to 5 ("strongly agree"). The alpha of the items assessing tolerance toward migrants was acceptable, and a mean index was thus used in the analysis $(\alpha=.72 ; M=3.37 ; S D=$ 1.04).

The analyses were conducted separately among adolescents and young adults, using the software SPSS 21. In the main analyses, tolerance toward migrants and tolerance toward refugees were regressed on the following variables: age, gender, migrant status, parents' education, school education and the four forms of participation.

\subsection{Results}

Table 5 presents the correlations between different forms of participation - civic, online, conventional political and protest - among adolescents and young adults.

Tab. 5 - Correlations between participation and tolerance among adolescents and young adults: Study 2

\begin{tabular}{|c|c|c|c|c|c|c|}
\hline & 1. & 2. & 3. & 4. & 5. & 6. \\
\hline $\begin{array}{l}\text { 1. Tolerance toward mi- } \\
\text { grants }\end{array}$ & - & $.752^{* *}$ & $.188^{* *}$ & -.015 & $.154^{* *}$ & .078 \\
\hline $\begin{array}{l}\text { 2. Tolerance toward refu- } \\
\text { gees }\end{array}$ & $.744^{* *}$ & - & $.205^{* *}$ & .002 & $.222^{* *}$ & $.126^{* *}$ \\
\hline 3. Online participation & .056 & .070 & - & $.479^{* *}$ & $.422^{* *}$ & $.322^{* *}$ \\
\hline $\begin{array}{l}\text { 4. Political participation } \\
\text { (conventional) }\end{array}$ & .011 & .085 & $.322^{* *}$ & - & $.397^{* *}$ & $.324^{* *}$ \\
\hline 5. Civic participation & $.173^{* *}$ & $.185^{* *}$ & $.342^{* *}$ & $.280^{* *}$ & - & $.278^{* *}$ \\
\hline 6. Protest & .005 & .027 & $.264^{* *}$ & $.510^{* *}$ & $.248^{* *}$ & 1 \\
\hline
\end{tabular}


In Table 6 and 7, we present the results of the regression analyses, among adolescent and young adults. Among adolescents, we present the results of the final models including also school climate - fairness, but we must note that the other significant variables remain significant also in the alternative model (without school climate).

Tab. 6 - Multilinear regression results: Study 2. Dependent variable: Tolerance toward migrants

\begin{tabular}{lcccc}
\hline & \multicolumn{2}{c}{ Adolescents } & \multicolumn{2}{c}{ Young adults } \\
\hline Variables & $\mathrm{F}$ & $p$ & $\mathrm{~F}$ & $p$ \\
Migrant status & & & & .029 \\
Gender (F) & 10.12 & .002 & .80 & .606 \\
Mothers' education & 41.37 & .000 & 0.27 & .322 \\
Fathers education & 5.33 & .021 & 0.98 & .672 \\
School climate - fairness & 0.58 & .448 & .18 & .000 \\
Online participation & 16.22 & .000 & & .000 \\
Political participation & 0.27 & .605 & 26.89 & .002 \\
(conventional) & 0.11 & .741 & 14.50 & .362 \\
Civic participation & 15.50 & .000 & 9.55 & .83 \\
Protest & .36 & .548 & & .070 \\
$\mathrm{R}^{2}$ & & & .061 & \\
Adjusted R & .128 & & & \\
\hline
\end{tabular}

Tab. 7 - Multilinear regression results: Study 2. Dependent variable: Tolerance toward ref-

\begin{tabular}{lcccc}
\multicolumn{3}{l}{ ugees } & \multicolumn{3}{c}{ Adolescents } & \multicolumn{2}{c}{ Young adults } \\
\hline Variables & $\mathrm{F}$ & $p$ & $\mathrm{~F}$ & $p$ \\
& & & & \\
Migrant status & 20.66 & .000 & 13.24 & .000 \\
Gender (F) & 21.35 & .000 & 3.09 & .079 \\
Mothers' education & 3.40 & .065 & 4.21 & .040 \\
Fathers education & 5.26 & .022 & 0.32 & .573 \\
School climate - fairness & 12.04 & .001 & & \\
Online participation & 0.35 & .555 & 24.75 & .000 \\
Political participation & 4.84 & .028 & 16.44 & .000 \\
(conventional) & 13.32 & .000 & 24.53 & .000 \\
Civic participation & 1.37 & .242 & 4.49 & .034 \\
Protest & & & & \\
& .126 & & .113 & \\
$\mathrm{R}^{2}$ & .115 & & .105 & \\
Adjusted $\mathrm{R}^{2}$ & & & & \\
\hline
\end{tabular}


Civic participation showed a significant effect in both subsamples (adolescents and young adults) on tolerance toward both migrants and refugees. The effect of online participation was significant on tolerance toward migrants and refugees only among young adults. Conventional political participation showed a significant effect on tolerance toward migrants among adolescents and young adults and, in a minor extent, on tolerance toward refugees only among young adults. The effect of protest was significant only on tolerance toward refugees, and only among adults. Other results, about fairness at school and socio-demographics, will be commented in detail in the general discussion.

\section{Discussion}

Results were largely consistent between the two studies and showed that some sociodemographic characteristics - being female, migrant, and with higher educated parents - were positively associated with higher tolerance toward migrants. More specifically, in accordance with our hypothesis H3 and the existing literature (e.g., Torney-Purta et al., 2001), in most of our subsamples, except for young adults in Study 2, being female was associated with higher levels of reported tolerance. Similarly, in most of our subsamples, except for young adults in Study 2 being born in another country was associated with higher levels of tolerance, consistently with H4. Mother's and father's education was associated with higher levels of tolerance in some of our subsamples, with an unclear pattern. In all cases, the effect was modest, suggesting that parents' education has some importance (according to H5), even if it is not the most relevant factor. Altogether, these results suggest that background characteristics, particularly gender and migrant background, impact the level of tolerance exhibited towards migrants.

However, the results from our two studies emphasized also the importance of factors that are more easily prone to change. Indeed, according to our main hypothesis $\mathrm{H} 1$, different forms of civic and political participation demonstrated a significant effect on tolerance, both toward migrants and refugees. More specifically, we found that civic forms of participation were the most predictive of tolerance, suggesting that these forms of participation provide more opportunities for contact with "differentiated others" in a democratic environment. For adolescents, in particular, civic engagement was most consistently linked to higher tolerance toward migrants and refugees, in concordance to observations of the preference for this form of participation in adolescence (Schulz et al., 2010). In this sense, civic engagement in the form of volunteering, membership in organizations, working on a social cause, 
may indeed represent a democratic training ground, in which living together and mutual respect for diversities can be developed. This result is consistent with the findings of Wise and Driskell (2017) who, in a large a sample of US adults, demonstrated a significant relationship between civic engagement and tolerance towards a number of different groups.

While most previous literature has linked volunteering and associational engagement with the development of tolerance (e.g., Rapp \& Freitag, 2014; Wise \& Driskell, 2017), our findings suggest that conventional forms of political participation and protest may also have an important role in promoting acceptance of societal diversity. Our results showed that conventional political participation was linked to both tolerance for migrants and for refugees in young adults, and only to tolerance for refugees in adolescents (Study 2). In addition to volunteering for civic causes, then, working for political parties and on political issues may also provide formative experiences of contact with diverse people and opinions, further influencing the development of tolerant attitudes toward migration. Moreover, our findings suggested that protesting might also have a beneficial effect on tolerance, particularly in emerging adulthood when the activity is more likely to be undertaken. Protesting was, in fact, significantly related only with tolerance toward refugees among young adults, suggesting that tolerance toward refugees would be more related with radical and manifest forms of participation (i.e., due to the politicization of the issue "refugees crisis").

Online participation was also associated with more tolerance only among young adults, probably because of the different use of Internet between adolescents (to communicate with their own peers' group) and young adults (to interact with a higher number of distant people).

These findings suggest that more research is needed on the processes and mechanisms through which diverse forms of participation may impact tolerance attitudes. For example, we found that the same type of activities online participation - may have different impact on tolerance in different age groups. We also noted that previously less considered forms, such as political participation, might also be relevant "schools for tolerance". These effects would need further examination in terms of the characteristics of engaging experiences that promote tolerance and the conditions in which each type of participative opportunity has an impact.

Some limits of this article must be recognized. First of all, the correlational nature of the study design does not to allow establishing a causal relationship between variables. Second, the measure of tolerance was probably able to assess the respondents' support for migrants' rights, but it was probably not able to perfectly assess the complexity of the tolerance construct that should imply the support for the inclusion of migrants despite 
apparent negative attitudes (Feitag \& Rapp, 2015). Further research, with longitudinal designs and more complex measures of tolerance and participation, will help in overcoming these limits.

The results of these two studies have important practical implications for the education system, especially if we consider that tolerant attitudes are regarded as an important aspect of mature citizenship achievement (Gniewosz \& Noack, 2008). Many years ago, Dewey (1916) postulated that teaching democratic values, which include tolerance, is an important task of schools and he further emphasized that it is not sufficient to learn these values by way of formal instruction as part of the curriculum, but it is crucial to experience tolerance and to act it out. Consistent with this view, global and European institutions have sought to promote different educational strategies to foster tolerance and awareness of human rights in youth. Indeed, UNESCO has promoted global citizenship education since the launch of the UN Secretary-General's Global Education First Initiative (GEFI) in 2012, which made fostering global citizenship one of its three education priorities (UNESCO, 2015). In this frame, tolerance is one key learning objective that should be reached together with other values and skills that enable people to live together peacefully. On a European level, too, education on competences required for intercultural dialogue is crucial for promoting tolerance, mutual respect and understanding, preventing conflicts, and achieving social cohesion (Council of Europe, 2008; European Union, 2017).

Overall, our findings emphasize the specific and important role that civic and political participation could play as a "school for democracy", in which young people may learn a range of civic skills and enhance their tolerance toward migrants. This may happen through different processes, for example, providing a context for intergroup contact, offering people from different backgrounds the opportunity to interact, sharing common goals and learning democratic values "in practice". In this sense, communitybased approaches are a powerful tool for promoting tolerance between migrant and non-migrant populations by engaging them in a participative and empowering process. In view of the results obtained from our studies, we stress the importance of targeting community programs both to migrant and native-born individuals to promote a common participation and coexistence. For example, community-based projects can be aimed at identifying common interests between diverse groups of young people, mobilizing peers, working collectively to address community and human rights issues in schools and communities, and promoting inclusiveness (Watts \& Flanagan, 2007). This recommendation is in line also with previous results which showed that young migrants' participation is associated with a higher sense 
of community to the local community, and with higher social well-being (Barbieri \& Zani, 2015). Indeed, even if a complete (i.e., without any kind of rejection) acceptance would be desirable, tolerance appears a more realistic goal that helps civil societies and communities to cope with rising levels of diversity stemming from immigration and individualism.

\section{Acknowledgments}

The research presented in Study 2 is based on data collected under CATCHEyoU project funded by European Union, Horizon 2020 Programme, Constructing AcTive CitizensHip with European Youth: Policies, Practices, Challenges, and Solutions (2015-2018) (www.catcheyou.eu) [Grant Agreement No 649538].

\section{References}

Abrams, D., \& Rutland, A. (2008). The development of subjective group dynamics. In S. R. Levy \& M. Killen (Eds.), Intergroup attitudes and relations in childhood through adulthood (pp. 47-65). New York, NY: Oxford University Press.

Arnett, J.J. (2004). Emerging adulthood: The winding road from the late teens through the twenties. New York: Oxford University Press.

Bansak, K., Hainmueller, J., \& Hangartner, D. (2016). How economic, humanitarian, and religious concerns shape European attitudes toward asylum seekers. Science, 22 Sep 2016. doi: 10.1126/science.aag2147

Barbieri, I., \& Zani, B. (2015). Multiple Sense of Community, identity and wellbeing in a context of multi culture: A mediation model. Community Psychology in Global Perspective, 1(2), 40-60. doi: 10.1285/i24212113v1i2p40

Benish-Weisman, M., Daniel, E., Schiefer, D., Möllering, A., \& Knafo-Noam, A. (2015). Multiple social identifications and adolescents' self-esteem. Journal of Adolescence, 44, 21-31. doi: 10.1016/j.adolescence.2015.06.008

Brechwald, W.A., \& Prinstein, M.J. (2011). Beyond homophily: A decade of advances in understanding peer influence processes. Journal of Research on Adolescence, 21, 166-179. doi: 10.1111/j.1532-7795.2010.00721.x

Cicognani, E., Noack, P., \& Macek, P. (2019). CATCH-EyoU. Processes in Youth's Construction of Active EU Citizenship. Italian Wave 1 Questionnaires. EXTRACT. Tolerance and Political Participation. University of Bologna. http://doi.org/10.6092/unibo/amsacta/6146 [Dataset]

Cortina, J.M. (1993). What is coefficient alpha? An examination of theory and applications. Journal of Applied Psychology, 78(1), 98-104. doi: 10.1037/00219010.78.1.98

Côté, R.R., \& Erickson, B.H. (2009). Untangling the roots of tolerance: How forms of social capital shape attitudes toward ethnic minorities and immigrants. American Behavioral Scientist, 52, 1664-1689. doi: 10.1177/0002764209331532 
Council of Europe (2008). White Paper on intercultural dialogue "Living together as equals in dignity”. Strasbourg: Committee of Ministers, Council of Europe. Retrieved from: http://www.coe.int

Dewey, J. (1916). Democracy and education: An introduction to the philosophy of education. New York, NY: Macmillan Publishing.

Emler, N., \& Frazer, E. (1999). Politics: The education effect. Oxford Review of Education, 25(1/2), 251-273. doi: 10.1080/030549899104242

Emler, N. (2005). Life course transitions and social identity change. Advances in Life Course Research, 10, 197-215. doi: 10.1016/S1040-2608(05)10007-0

Escandell, X. (2004). The impact of political engagement on social and political tolerance toward immigrants in Southern Europe. UC San Diego: Center for Comparative Immigration Studies. Tratto da https://escholarship.org/uc/item/3032c686

European Union (2017). How culture and the arts can promote intercultural dialogue in the context of the migratory and refugee crisis. Report with case studies, by the working group of EU Member States' experts on intercultural dialogue in the context of the migratory and refugee crisis under the open method of coordination. Luxembourg: Publication office of the European Union. doi: $10.2766 / 468525$

Flanagan, C., \& Levine, P. (2010). Civic engagement and the transition to adulthood. The Future of Children, 20(1), 159-179. https://files.eric.ed.gov/fulltext/ EJ883084.pdf

Freitag, M., \& Rapp, C. (2015). The personal foundations of political tolerance towards immigrants. Journal of Ethnic and Migration Studies, 41, 351-373. doi: 10.1080/1369183X.2014.924847

French, S.E., Seidman, E., Allen, L., \& Aber, J.L. (2006). The development of ethnic identity during adolescence. Developmental Psychology, 42, 1-10. doi: 10.1037/0012-1649.42.1.1

Gerson, M.W., \& Nielson, L. (2014). The importance of identity development, principled moral reasoning, and empathy as predictors of openness to diversity in emerging adults. SAGE Open, October-Dicember 2014, 1-11. doi: $10.1177 / 2158244014553584$

Gniewosz, B., \& Noack, P. (2008). Classroom climate indicators and attitudes towards foreigners. Journal of Adolescence, 31, 609-624. doi: 10.1016/ j.adolescence.2007.10.006

Hahn, C.L. (1999). Citizenship education: an empirical study of policy, practices and outcomes. Oxford Review of Education, 25(1-2), 253-250. doi: 10.1080/ 030549899104233

Hjerm, M. (2009). Prejudice toward immigrants and cross-municipal variation in the proportion of immigrants. Acta Sociologica, 52, 47-62. doi: 10.1177/ 0001699308100633

Langerak, E. (1994). Pluralism, tolerance, and disagreement. Rhetoric Society Quarterly, 24, 95-105. doi: 10.1080/02773949409391008

King, P.M., \& Baxter Magolda, M.B. (2005). A developmental model of intercultural maturity. Journal of College Student Development, 46, 571-592. doi: $10.1353 /$ csd.2005.0060 
Kubal, T., Stone, R.T., Meyler, D., \& Mauney, T.T. (2003). Teaching diversity and learning outcomes: Bringing lived experience into the classroom. Teaching Sociology, 31, 441-455. https://www.jstor.org/stable/3211368

Mazzoni D., Cicognani E., Tzankova I., Guarino A., Albanesi C., \& Zani B. (in press, 2019). Civic participation and other interventions that promote children's tolerance of immigrants. In N. Balvin \& D. Crisitie (Eds.), Children and Peace: From Research to Action. Springer.

Raabe, T., \& Beelmann, A. (2011). Development of ethnic, racial, and national prejudice in childhood and adolescence: A multinational meta-analysis of age differences. Child Development, 82(6), 1715-1737. doi: 10.1111/j.14678624.2011.01668.x

Ramberg, I. (2005). Committed to making a difference. Racism, antisemitism, xenophobia, and intolerance and their impact on young people in Europe. Hungary: Council of Europe.

Rapp, C. (2017). Shaping tolerant attitudes towards immigrants: The role of welfare state expenditures. Journal of European Social Policy, 27, 40-56. doi: $10.1177 / 0958928716672181$

Rapp, C., \& Freitag, M. (2014). Teaching tolerance? Associational diversity and tolerance formation. Political Studies, 63, 1031-1051. doi: 10.1111/1467-9248.12142

Schulz, W., Ainley, J., Fraillon, J., Kerr, D., \& Losito, B. (2010). ICCS 2009 international report: Civic knowledge, attitudes, and engagement among lowersecondary school students in 38 countries. Amsterdam: International Association for the Evaluation of Educational Achievement (IEA).

Streiner, D.L (2003). Starting at the beginning: An introduction to coefficient Alpha and internal consistency. Journal of Personality Assessment, 80(1), 99-103. doi: $10.1207 /$ S15327752JPA8001 18

Torney-Purta, J., Lehmann, R., Oswald, H., \& Schulz, W. (2001). Citizenship and education in twenty-eight countries: Civic knowledge and engagement at age fourteen. Amsterdam: International Association for the Evaluation of Educational Achievement.

UNESCO (1995). Declaration of principles on tolerance (16 November 1995). Tratto da http://portal.unesco.org

UNESCO (1997). Defining tolerance. Tratto da http://unesdoc.unesco.org

UNESCO (2015). Global Citizenship Education: Topics and learning objectives. Paris: United Nations Educational, Scientific and Cultural Organization. Tratto da http://unesdoc.unesco.org

Van Zalk, M.H., \& Kerr, M. (2014). Developmental trajectories of prejudice and tolerance toward immigrants from early to late adolescence. Journal Youth Adolescence, 43, 1658-1671. doi: 10.1007/s10964-014-0164-1

Van Zalk, M.H.W., Van Zalk, N., Kerr, M., \& Stattin, H. (2013). Xenophobia and tolerance toward immigrants in adolescence: Cross-influence processes within friendships. Journal of Abnormal Child Psychology, 41, 627-639. doi: $10.1007 / \mathrm{s} 10802-012-9694-8$

Verkuyten, M. (2018). The benefits of studying immigration for social psychology. European Journal of Social Psychology, 48(3), 225-239. doi: 10.1002/ejsp.2354 
Verkuyten, M. \& Yogeeswaran, K. (2017). The social psychology of intergroup toleration: A roadmap for theory and research. Personality and Social Psychology Review, 21(1), 72-96. doi: 10.1177/1088868316640974

Watts, R., \& Flanagan, C. (2007). Pushing the envelope on youth civic engagement: A developmental and liberation psychology perspective. Journal of Community Psychology, 35, 779-792. doi: 10.1002/jcop.20178

West, S.G., Finch, J.F., \& Curran, P.J. (1996). Structural equation models with nonnormal variables: problems and remedies. In R.H Hoyle (Ed.), Structural equation modeling: Concepts, issues and applications (pp. 56-75). Newbery Park, CA: Sage.

Wise, J. \& Driskell, R. (2017). Tolerance within community: Does social capital affect tolerance? Social Indicator Research, 134, 607-629. doi: $10.1007 / \mathrm{s} 11205-016-1449-4$ 